(ISSN: 2610-9182)

\title{
Secondary Socialization of Homeschoolers during the Covid-19 Pandemic
}

\author{
Václav Šimek ${ }^{1}$, Albert Oláh ${ }^{1}$, Kateřina Bočková ${ }^{2 *}$ \\ ${ }^{1}$ Department of Didactics of Specialized Subjects, DTI University, Sládkovičova 553/20, 01841 Dubnica nad Váhom, Slovakia \\ ${ }^{2}$ Department of Management and Economics, DTI University, Sládkovičova 553/20, 01841 Dubnica nad Váhom, Slovakia
}

\begin{abstract}
The presented article deals with the description of the socialization of basic school pupils, i.e pupils in younger and middle school age, who fulfill the compulsory school attendance in the form of individual education (homeschooling) in the context of the legislation of the Czech Republic. In the context of fulfilling the article aim, we formulated three research questions, which were evaluated using quantitative research in the form of a questionnaire survey. The research confirmed that parents of homeschoolers significantly support their children in participating in organized leisure activities and are actively involved in mediating their child's contact with other children. In the comparison of the examined groups there were no significant differences in how the children perceive their friends, what their favorite activities are or how much time they spend with them. The difference was more noticeable in the parental approach in education, when setting some rules. This article can outline areas that can be further explored in more detail and compared in context.
\end{abstract}

\section{Keywords:}

Homeschooling;

Individual Education;

Socialization;

Compulsory School Attendance.

Article History:

Received: 10 July 2021

Revised: $\quad 15 \quad$ September 2021

Accepted: 26 September 2021

Published: 11 October 2021

\section{1- Introduction}

Socialization is considered to be the most discussed topic in homeschooling, and insufficient socialization is the most frequently cited reason for opponents of this alternative style of education. Two completely different views on socialization come into conflict. Some argue that children educated at home live in isolation and grow up in so-called greenhouse conditions, others assume that the home environment is more suitable for socialization than a school in which there are many negative influences from which parents want to protect their descendants. Several studies on the socialization of children in homeschooling, such as Kunzman and Gaither [1], Medlin [2], Ray [3, 4], point to the fact that homeschoolers are developing just as well socially if not better than normal school children. For example, an analysis of homeschooling outcomes in the United States confirms that homeschoolers are mature, have good leadership skills, interact well with both peers and adults, have no social anxiety and problematic behavior. Overall, they are manifested by prosocial behavior and social responsibility [5]. School and family are inseparable in one way or another, and how a child is doing at school is not only his personal identity, but also an indicator of family functionality [6]. And although the two institutions differ in many ways, they have one thing in common: to ensure the child's maximum development.

\section{*CONTACT: bockova@dti.sk}

DOI: http://dx.doi.org/10.28991/esj-2021-SPER-12

(C) 2021 by the authors. Licensee ESJ, Italy. This is an open access article under the terms and conditions of the Creative Commons Attribution (CC-BY) license (https://creativecommons.org/licenses/by/4.0/). 
The family is the primary group for a child, in which his or her personality is formed from birth to life, and at the same time represents a safe, emotional and supportive environment [7-8]. During the socialization process, the child is affected by patterns (parents, older siblings), either positively or negatively. Parents can also be "models for the future" for their descendants, which consists in a child's idea of their own future, which is identical with the life of the parents [8]. The family lays the foundation for the child in the ability to establish social relationships and prepares him or her for practical life [9]. It is also responsible for the upbringing of children and plays a key and irreplaceable role in this regard. It is family education that is important in creating a child's relationship with society in the sense that he or she is informally influenced by the views of his or her parents [10]. The social environment and society can be perceived by individuals as an advantage and a part of life, or, conversely, as a certain limitation. The way of this perception is predetermined already in the microenvironment by the style of education already taking place in early childhood [11]. There is a positive socialization in the family, which is connected with the child's self-esteem and his or her feeling of being needed and wanted. This then leads to the child being independent and peer group in society. The child should remain in the family environment and should not be included in a larger group until he or she is able to think independently [12]. It is even better to wait until the child itself requires the contact of other children, but ultimately depends on the social maturity of the child [13].

The undeniable advantage of homeschooling is that the family spends more time together, which leads to the favorable development of the child [14]. Common experiences form family history and participate in mutual coexistence [8]. Also important is the relationship between siblings, which brings some social experience. Siblings compete with each other, learn to work together and influence each other. Sibling cohabitation to some extent also depends on whether their parents treat all children in the same way [8]. It can be assumed that in families with more children, socialization within the family can be ensured. However, what may seem problematic are families with only ones. According to [15], a nationwide study of academic success and demographic traits of homeschoolers conducted on 11739 pupils from homeschooling, only one child has $6.6 \%$ of families. On average, there are 3.5 children under the age of 21 in families with homeschooling. The average number of children in families in the United States under the age of 18 in 2010 , when the above-mentioned research was conducted, was 1.88 children [16].

Although the family is considered primarily as a place for primary socialization, in the case of homeschooling it is necessary that secondary socialization is also ensured in some way. Therefore, it is important that the family does not live in isolation, but that it is in regular contact with support groups or communities of schoolchildren. These communities tend to be very helpful not only for starting families with homeschooling. There is mutual support, organization of joint events, transfer of experience with pedagogical methods, suitable textbooks and various teaching aids that can make learning at home more effective [17]. Support groups are not only for mothers (parents) who exchange their experiences, advice and tips with homeschooling, but also for mothers (parents) just with children [18]. Even in hobby groups, sports clubs or other social facilities, children from homeschooling have the opportunity to get in touch with a very wide range of peers, as well as with an age-heterogeneous team [19]. Another way to be in contact with other homeschooling-based families are social networks, through which it is possible to connect with families operating homeschooling from all over the country. Parents can share their successes and failures, counsel and support each other. They can then find more professional help on portals dealing with homeschooling or directly in schools that offer online counseling with a school psychologist [20].

Many people have an experienced idea that socialization takes place right and especially at school, and without this institution the child will be strange, impoverished, will not have enough "sharp elbows" to break through life. In a deeper discussion of what is important for the mother in the upbringing of the child, we came to the consensus that in upbringing in institutions the parent has little opportunity to influence which adults the child encounters, what are their value and moral foundation and how much time then affects the child. What group of children will be admitted to the class and whether the teacher will be able to put together this puzzle so that the positives from school attendance outweight the negatives? Therefore, the aim of the presented article is to describe and compare how the socialization of children who fulfill the compulsory school attendance in the form of individual education (homeschooling) takes place.

The presented article has a standard structuring of the scientific article. After the introductory part processed in the form of a general introduction to the issue, the theoretical part is processed in the form of a secondary analysis based on a critical analysis of information sources. Czech information sources are primarily used, as the issue of homeschooling is new in the Czech Republic, only 5 years ago enshrined in legislation, still insufficiently researched in its principles and therefore in a way specific. Thus, the definition of the basic elements of secondary socialization and socialization in the context of Czech homeschooling according to foreign information sources could thus create ambivalence in the issues addressed and thus the irrelevance of the information and data used. In this part of the article, attention is paid to general issues of socialization of children in the educational process with regard to the development of the child's personality. The methodological part follows, where the research problem and relevant research questions are formulated. We also justify the choice of quantitative research in the form of a questionnaire survey, which we describe in more detail and specify its course and evaluation. 
The following is a presentation of the results of a questionnaire survey focused on our comparison of the course of socialization of children in ordinary basic schools and in homeschooling, the method of socialization of children in families who have longer experience with homeschooling is also examined. The identified outputs are summarized here in the form of answers to research questions, they are also compared with the outputs of available research focused on the socialization of homeschoolers again with the above reasons using primarily Czech information sources.

\section{2- Literature Review}

The topic of socialization is very extensive. It is a part of psychology, social pedagogy and sociology. Nakonečný [23] quotes Zigler and Child in explaining the concept of socialization: "Socialization is a broad concept for the overall process in which the individual develops his own socially relevant pattern of behavior and experience through active interaction with other people." Neuman and Guterman [24] as well state that the topic of socialization is a central topic of social psychology, because it explains how the child becomes active. At the same time, it also explains the dependence of a social being on a certain fund of social attitudes and patterns of social behavior, which is regulated by his or her other life experiences, resp. expanded. In the psychological dictionary [25-27], the motto of socialization is understood as the integration of an individual into society. It occurs through imitation and identification. Hartl et al. (2010) [25] states that "imitation refers to the conscious or unconscious repetition of behavior". VandenBos (2007) [26] further writes that "identification is, for example, an individual's identification with his own sexual role". Inclusion occurs first in the nuclear family, then in small social groups (e.g. school class), gradually becoming involved in the broadest societal relationships [28].

Medlin [29] also considers socialization as a way of "transforming a biological individual into a social being who has a specific human psyche." Romanowki [30] includes a very extensive process of transformation in socialization, which begins with the acquisition of basic cultural habits. As already mentioned, the individual later identifies with the role of his gender, begins to orient himself in the world of values, which he further internalizes. According to Nakonečný, socialization is mainly social learning. Čabalová [31] writes about socialization as an active activity. Cábalová (2011) she defines socialization as the development of the individual as a social being who in time actively integrates into the society in which he lives. "The socialization process is a kind of acceptance and mastery of mutual interaction and communication", which takes place with other individuals, across society, acceptance of values and is given by culture. Socialization is a lifelong process that takes place from childhood to old age. The view of the sociologist Josef Alan also mentions the active participation of an individual in socialization, by creating his claims (interests), which are a motivating element. By doing so, one learns in socialization how to live in accordance with one's social environment [32].

The British sociologist Anthony Giddens describes the influence of socialization on the formation of intergenerational links, where from a newborn throughout his life, the individual perceives himself and orients himself in his culture. Giddens (1999) also links socialization to the perception of individual freedom. When the cultural environment, in which an individual is born and grows, has a great influence on human behavior. It might seem that the individual is deprived of any individuality or free choice. It might seem to us that we will only be included in the preprepared boxes that the society has prepared for us. We must acknowledge that such thoughts are not foreign to us. That during the development of us a certain program is installed, according to which we then realize our life. Giddens, however, considers this reasoning to be wrong. The fact that people are in interactions with others from birth to death certainly has an effect on the formation of personality, on the values that it professes and on the action itself. But within the framework of socialization, the foundations of our own individuality and freedom are also laid. In this process, each person reaches self-awareness and develops the ability to think and act independently [33]. It follows from the above definitions that there is no uniform explanation of the concept of socialization. But we think that the authors agree that socialization refers to a process. It does not end when the children leave the home of the primary family, or when they reach a certain education, but it lasts a lifetime.

Štech [6] and Medlin [2] as well ask the question whether the family and the school have the same function in socialization and whether they fulfill it in the same way. Wyatt [34] points out that with the development of the so-called modern society, emphasis is placed on the individual and his autonomy, and with that solidarity gives way in the name of higher values. To understand school socialization, Štech [6] also presents the historical context. In modern times, on the one hand, there was a change in the way society was reproduced, which was caused by urbanization. To make a living, family members left their households. Štech quotes Adler: "Schools were established because the family was not able to raise children to meet the social demands of life - school is an extension of the family and it is it that the character of the child is largely formed and it is in them that children learn to face life's problems" (Štech [6]) and further considers whether this situation has changed so much with the employment of parents outside the home and the provision of facilities for children in schools to this day? Here we agree with Štech, because many families still devote themselves to there is not much time left to provide the necessary livelihood for the family and for the care and education of the children themselves, which is why parents are happy to entrust their child to a school, but there are also more families who can and want to spend more time with children and at the same time they do not neglect the socialization 
side. Drenovsky and Cohen [35] in the historical context point to the "need to protect the child and to be aware of his vulnerability and special needs", as well as to the "need for effective education of children". We would stop at the "need to create a cohesive community". The author emphasizes that this need is also relevant in today's society, thanks to the increasing atomization of social life and significant individualization. However, it would be possible to argue with Štech [6] here as to whether the school really makes it possible to create a cohesive community today?

In connection with the school, Blok (2004) [36] also mentions cognitive socialization. The point is that school and the ways in which knowledge is passed on here are linked to cognitive socialization. It is a crucial factor in creating the individual's mental structures. At school, the author also sees the advantage that children selected more or less randomly meet here. They have to adapt and learn to work in social contact with people who would not meet in the family or who would not choose for themselves. Stech considers the situation where the child lives in school mainly in agehomogeneous groups to be a desirable division for identity development. According to him, the child should be aware of the differences between the world of children and adults, but also the world of small and large pupils (meaning firstgraders compared to third-graders or fifth-graders). What someone at a certain age or class can and another not yet. Štech states that this should contribute to the structuring of the world as well as to the necessary informal transition rituals. Štech [6] and Murphy [37] also develops the idea that in our culture a child could not succeed without school. They explain the statement by saying that "the institution of the school is a part of our culture to the extent that it further counts on its mental effects" [6]. In a similar sense, it states that "the socialization of children is now unimaginable outside school". For these and other reasons, Murphy (2014) [37] considers a form of homeschooling only as a marginal alternative, not as an equivalent alternative to school education.

Contrary to Štech's interpretation [6], we can mention the work of Mertin [14], who takes a different view of socialization and contact with peers. He agrees that from a certain age, children have a strong desire for peers. He reminds that the dynamics of peer relationships is also used in cooperative learning. Mertin states that many schools are already significantly individualizing their approach to children, trying to incorporate elements of social skills development, linking learning with the experience of the child's life and society. However, not all families and their children have schools with such an approach in their surroundings. However, [14] points out that only permitted forms of social contact still persist in schools: "they must not speakl, copy, talk to each other during class. Children are allowed to talk about breaks, not to wash, to shout" (2003). In defending the form of homeschooling, he points to the investigation of Taylor and Petrie [14], which shows that children educated at home entered into contacts with peers and adults without problems. They also justify this by the fact that the parents of these children support their social contacts more significantly. In addition, in homeschooling, according to Mertin [14], parents and children have more time together for many activities in which they can share their feelings. "From the degree and quality of contacts with important adults, the child derives part of his progress and development." He states that there is a danger of anonymity, loss of responsibility, and contacts between teachers and pupils are not very personal.

Kostelecká also considers the issue of socialization in her study [38]. She points out that there is a widespread belief that children at home have some problems with socialization, although this is not evidenced by any studies published so far that have compared the social skills of children in school and children in homeschooling. Kostelecká [38] summarizes that "socialization is primarily a matter of adapting the individual to a certain group, its values, norms and ways of acting." But it points out a possible problem. It lies in the fact that we live in a modern society, which is often multicultural. Which means that it consists of representatives of different groups that share different values. The problem or question then remains, what values should the child learn in socialization and which groups to adapt to. According to Kostelecká [38], socialization itself may not be neutral at all, but positive or negative. According to her, the positive one is connected with the family, with the amount and quality of self-esteem that the child acquires. According to the Kostelecká [38], if a child feels that he or she is loved and wanted, then he or she can behave more independently and independently in the team. It also has a greater tendency to avoid antisocial to antisocial pathological phenomena associated with peer dependence. Kostelecká [38] or Schechter and Vahid [39] also speculate about the benefits of socialization in a group of peers, and the results of research by the developmental psychologist Bronfenberenner are added to this. Research conducted among sixth-graders in basic school has shown that peer orientation and preference "is a way out of need for children rather than a free choice". In finding out how the child's orientation towards peers arises, Bronfenberenner describes the effect of a lack of interest and attention from parents, little-expressed affection and support from parents. Jančaříková [17] further states that on the basis of her own research she sees that for the longterm functioning of homeschooling it is necessary for the family to be involved in the community. For example, for a good family connection to work with a group of other families educating children at home. So that the family does not live in isolation.

The relatively new study Self-Concept of Home Education Graduates and Their Classmates [40] deals with a subtopic of socialization. Its aim was to find out how children who have undergone homeschooling perceive themselves and to compare the results with classmates without this specific experience. The authors of this study compared their data with Taylor's study from the United States of America from the 1980s and 1990s. Kostelecká et al. [40] stated that "when a child's self-concept is a reflection of socialization, few homeschoolers appear to be socially deprived". 
Kostelecká et al. [40] pointed out that children's self-concept was significantly more negative with increasing age and year of education. Conversely, factors such as the gender of the child, the number of siblings, place of residence, previous school attendance or the level of education of the educator did not affect the self-concept. On the other hand, the inclusion of the family in a higher socio-economic status and also a higher number of homeschoolers in the family proved to be statistically significant. These factors had a positive effect on the child's socialization.

A systematic review study of homeschoolers and various aspects of their socialization was prepared by Medlin [2]. The results summarize research-based data from studies focused on social skills, moral and spiritual development, emotional intelligence, and the transition to adulthood. Medlin [2] asks the question: "Do homeschoolers acquire the skills, behaviors, values and motivations they need to function as competent members of society?" Based on studies, the answer to this question is unequivocally "yes" ". The results of the Kostelecká et al. (2018) [40] noted very small and statistically insignificant differences between respondents with experience in homeschooling and their classmates. The authors of other studies, such as [29, 30, 41-43, 46, 47], achieved the same results.

\section{3- Materials and Methods}

In the research part, we planned to use a combination of qualitative and quantitative research. The qualitative part with the methods of observation and interview was to focus on families educating their children in another form of education, resp. in the form of homeschooling, so that we can obtain information about what the reality is, what these families and children really are, how they see themselves or what they enjoy. However, given all the limitations of personal contact due to the spread of Covid-19, we had to omit this part of the research. We rejected the online interview option because it would not meet our requirement to get to know families better and get closer to children. Therefore, we chose only a quantitative approach and a questionnaire method for the research, which was to enable us to compare the statements of the group educating children in the form of homeschooling and the group educating children in the form of regular attendance at basic school. We formulated the research problem with the question: What are the differences in the socialization of children educated in basic schools and homeschoolers?

In the context of the research problem and the research goal, we ask the following research questions:

RQ1: What environment or activities do parents use to support their children's socialization?

RQ2: What is the motivation of parents to choose the homeschooling for their children?

RQ3: What are the differences in the socialization of pupils attending basic school against homeschoolers, resp. what are the differences in the involvement of children in the team, differences in leisure activities, differences in leisure preferences?

\section{3-1- Questionnaire Survey}

To collect data, we used the questionnaire method, which allowed us to obtain a large amount of data from a larger number of respondents in a relatively short time. The reliability of this research was influenced to a large extent by the obtained research set, which was compiled by the method of occasional selection. It does not guarantee the representativeness of the sample, and therefore we can obtain different data by repeatedly using a research tool on another research set. At the same time, some questionnaire items focus on the subjective perception of respondents influenced by the time in which respondents provided their answers. Therefore, the results of our research cannot be generalized, they will be valid only for the families that were part of it.

We tried to ensure the validity of the research tool through pre-research, where we verified the correct formulation of questionnaire items and their unambiguous understanding for respondents so that they could really answer what we want to ask them. The preliminary survey took place in October 2020 and was attended by 15 respondents. From this preliminary research, we gained some insights into the comprehensibility of the questions. Therefore, we completely excluded some from the questionnaire, because the reaction of the respondents was such that the questions for children are too abstract and difficult to answer. Therefore, the answers obtained might not be meaningful. We also excluded questions about customs, values and traditions because it gained too much scope for the questionnaire. It would be too long for respondents to fill out.

In the research tool - the questionnaire - we tried to capture the essence of the research goal so that we can answer the set research questions by analyzing the obtained data. A questionnaire survey was conducted in November 2020. The questionnaire is divided into several parts. The introductory part contains information about the purpose of the questionnaire and instructions for filling it out. The following is a section with questionnaire items (questions). We divided this area into an introductory part for respondents - children and further for respondents - parents. We supplemented the questionnaire items aimed at parents with questions that are only for parents of homeschoolers. When filling in question no. 18, the respondents were divided into two groups. Firstly, families who have a child educated by 
regular attendance at a school institution and the other part of families who have a homeschooler (School Act No. 561 [21], \$42 speaks of individual education). Subsequently, in the group of respondents who have children educated at school, questions No. 19-23 were skipped. In the final part of the questionnaire, we placed an item where the respondents can add a note to specify their answers.

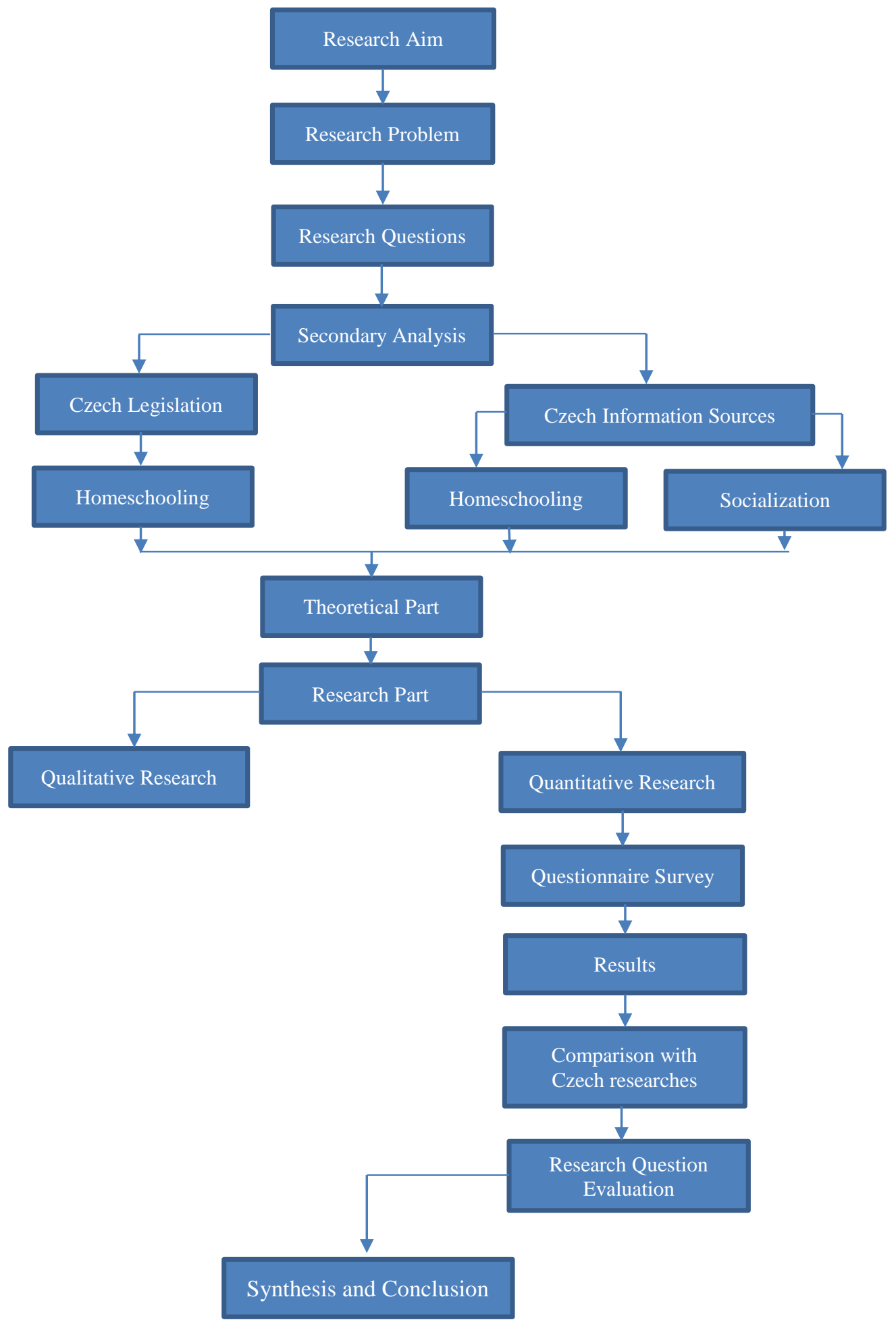

Figure 1 Methodology flowchart

The previous division of questionnaire items is related to the division of the respondent's role. At the same time, we divided the questionnaire into several areas according to thematic content. Demographic data of respondents (gender, age, grade of basic school, residence by number of inhabitants) are ascertained by questionnaire items No. 1-3 (for children) and items No. 14-16 (for adults). Items 4 and 17 collect data on the number of children's siblings and the number of household members. 
Socialization of children, resp. growing into interpersonal relationships and forming "we" attempts to capture items 5-8 (for children) and 24-27 (for parents). We used questions to find out how many good friends the children have, how satisfied they are with relationships with other children, what they like to do with the children and how much time they can spend with good friends. We asked parents for their opinion on where and on what occasions their children meet other children. In the area of shaping the lifestyle, as described by Řezáč [11], we included items to find out whether children have any patterns, whether they are inspired by some characters and, if so, whether children are influenced by people around them. These are questionnaire items No. 9-13. In this area, we asked parents how their children spend their leisure time. Whether the children have any organized leisure activities and, if so, which ones (questionnaire items no. 33 and 34). How much time do they spend outside and with electronics, or do they somehow limit their time with electronics (questionnaires items 28-31).

A separate area of research is represented by questionnaire items No. 19-23. These are questions asked only to parents of homeschoolers. The items find out what the current form of education of the child is, whether, for example, the child attends community school, is educated by parents at home, etc. We also ask parents if they have experience with other forms of education of their children. How many children in homeschooling they have at home now and how many years do parents have experience with their child's homeschooling.

An important item for the evaluation was the question of the reasons that led the parents to request homeschooling.

We compiled the final form of the questionnaire on the website: www.survio.cz.

The method of occasional selection was applied when compiling the research file. "Individuals who are on hand are selected for the sample. It does not guarantee the representativeness of the sample at all. It is suitable for pilot research and pre-research" [22].

Using the method of occasional sample selection, 124 children and their parents responded to the research and responded to the questionnaire items. The children were 75 girls $(60.5 \%)$ and 49 boys (39.5\%). Among parents, there were 113 women $(91.1 \%)$ and 11 men $(8.9 \%)$. The set is further divided into two parts according to the method of fulfilling compulsory school attendance into a group of respondents who have "regular attendance at a school institution" (hereinafter BS group) and a group with "homechooling" (IV group). A total of 71 respondents with "regular school attendance" and a total of 53 respondents with "homeschooling" took part. When evaluating data with the number of child respondents, we continue to work mostly with age groups 5 - 7 years, 8 - 11 years and 12 - 15 years. Data on the representation of respondents in age categories show that the relative frequency for groups BS group and IV group is almost comparable in all categories. The following graph clearly shows this.

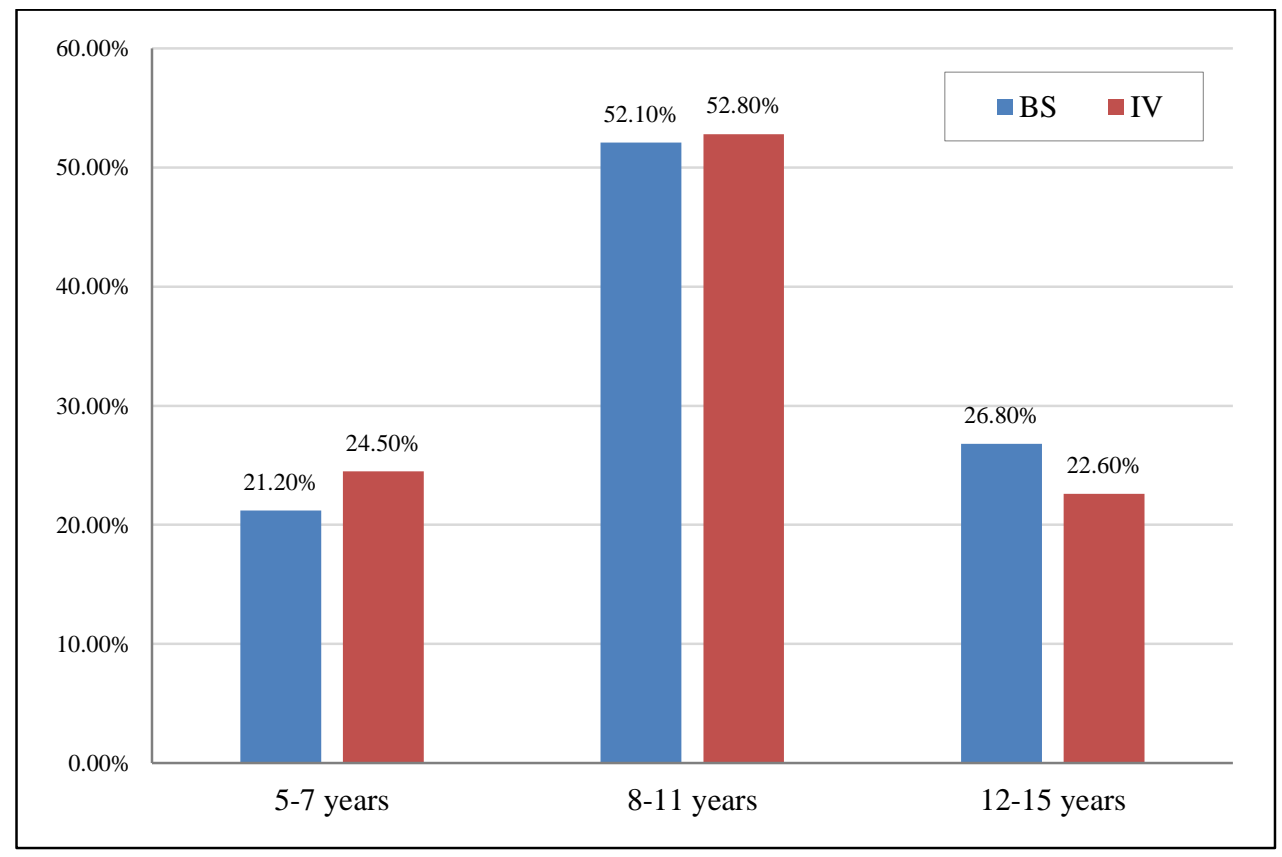

Figure 1. Age groups of respondents (children)

Similarly, comparable data on the relative frequency of age representation in BS group and IV group also show data obtained from parents. The most represented age categories 30 - 39 years differ by $6 \%$ between groups, the age category 40 - 49 years has almost $40 \%$ of respondents in each group. 
Table 1. Distribution of age and gender of respondents (parents).

\begin{tabular}{|c|c|c|c|c|c|}
\hline & \multirow{2}{*}{ Age according to respondents } & \multicolumn{2}{|c|}{ Gender Frequency } & \multicolumn{2}{|c|}{ Total Frequency } \\
\hline & & Man & Woman & Absulute & Relative \\
\hline \multirow{5}{*}{ PS } & To 29 & 0 & 4 & 4 & $5.6 \%$ \\
\hline & $30-39$ & 5 & 31 & 36 & $50.7 \%$ \\
\hline & $40-49$ & 3 & 26 & 29 & $40.8 \%$ \\
\hline & $50-59$ & 0 & 2 & 2 & $2.8 \%$ \\
\hline & Total & 8 & 63 & 71 & $100 \%$ \\
\hline \multirow{6}{*}{ IV } & Do 29 & 0 & 1 & 1 & $1.9 \%$ \\
\hline & $30-39$ & 2 & 28 & 30 & $56.6 \%$ \\
\hline & $40-49$ & 1 & 20 & 21 & $39.6 \%$ \\
\hline & $50-59$ & 0 & 1 & 1 & $1.9 \%$ \\
\hline & Total & 3 & 50 & 53 & $100 \%$ \\
\hline & Total BS + IV & 11 & 113 & 124 & $100 \%$ \\
\hline
\end{tabular}

In the questionnaire survey, we also found out which grade of basic school the child is currently attending. Respondents in the category of preschoolers up to the second grade are represented by $25 \%$ in BS group and by $30 \%$ in IV group. Third- to fifth-grade respondents are represented in the BS group by $46 \%$ and by $44 \%$ in IV group. Sixth to ninth grade respondents are represented in the BS group by $28 \%$ and in IV group by $26 \%$.

\section{4- Findings and Discussion}

Below we present the most fundamental findings of our research focused on the secondary socialization of Czech homeschoolers. When monitoring the place of residence, we found that more than one third of respondents (38\%) lives in the village, more than a third (36\%) in larger cities (with a population of more than 100 thousand inhabitants) and the remaining part of approximately a quarter of all respondents $(27 \%)$ are still divided to the inhabitants of small and medium-sized towns. The first two thirds of respondents described are almost evenly distributed in the BS and IV group.

Statistical differences can be observed between BS group and IV group in the category of urban population up to 10 thousand inhabitants, where the BS group shows $8 \%$ more than IV group and in the category of urban population up to 50 thousand inhabitants shows BS group 8\% less than IV group. The place of residence may affect the child 's development with regard to access to the wild safety around the place of residence, taking into account the availability of cultural, social and other experiences.

Table 2. Residence of respondents.

\begin{tabular}{|c|c|c|c|c|c|c|}
\hline \multirow{3}{*}{$\begin{array}{c}\text { Place of residence of respondents by } \\
\text { number of inhabitants }\end{array}$} & \multicolumn{2}{|c|}{ BS } & \multicolumn{2}{|c|}{ IV } & \multicolumn{2}{|c|}{ Total BS + IV } \\
\hline & \multicolumn{2}{|c|}{ Frequency } & \multicolumn{2}{|c|}{ Frequency } & \multicolumn{2}{|c|}{ Frequency } \\
\hline & Absolute & Relative & Absolute & Relative & Absolute & Relative \\
\hline city up to 10 thousand inhabitants & 15 & $21.1 \%$ & 7 & $13.2 \%$ & 22 & $17.7 \%$ \\
\hline city between 10 thousand - 50 thousand inhabitants & 4 & $5.6 \%$ & 7 & $13.2 \%$ & 11 & $8.9 \%$ \\
\hline city with more than 100 thousand inhabitants & 26 & $36.6 \%$ & 18 & $34.0 \%$ & 44 & $35.5 \%$ \\
\hline village & 26 & $36.6 \%$ & 21 & $39.6 \%$ & 47 & $37,9 \%$ \\
\hline Total & 71 & $100.0 \%$ & 53 & $100.0 \%$ & 124 & $100.0 \%$ \\
\hline
\end{tabular}

In the questionnaire, we further examined what is the most popular activity of respondents in contact with friends or other children. They were free to write down what they liked to do. Among the most frequently mentioned activities, living outside (BS 28.2\% and IV 37.7\%) and playing (BS 35.2\% and IV 32.1\%) predominated. Other occurrences include exercise / sports (BS 18.3\% and IV 28.3\%) and electronics playing (BS 16.9\% and IV 11.3\%). When asking the respondents about their friends, we were interested in how they perceive their relationships with other children and how satisfied the respondents are with the relationships they have with other children or friends. In the questionnaire, respondents had the opportunity to choose on a scale of satisfaction from a value of minus two, which meant very dissatisfied through a neutral zero to a value of plus two, which meant very satisfied. None of the respondents chose 
very dissatisfied, i.e. the value minus two. The value dissatisfied, i.e. minus one, was chosen by one respondent in BS group and one in IV group. Both in the age category of 12 - 15 years. It could be said that this corresponds to the fact that at this age children are very critical of the relationships they experience. However, the majority of respondents in both BS group (81.7\%) and IV group $(86.8 \%)$ said that they were very satisfied with the relationships they had with other children or friends.

When asked about the number of good friends, we obtained data from the respondents that $4 \%$ of respondents (BS $4.2 \%$ and IV $3.8 \%$ ) feel that they do not have any good friends with whom they would get along. Two respondents (3.8\%) from IV group did not answer the question. Everyone else said they had a good friend or comrades. Even more than five good friends were identified by 8 respondents from the BS group (11.3\%) and 11 respondents from IV group $(20.8 \%)$.

We also asked respondents to try to assess how much time they could spend with their good friends during the week. The largest share on weekdays in the BS group as well in IV group was represented with a response of 1 - 2 hours (BS $38 \%$ and IV 28.3\%), followed by a response of $31-60$ minutes (BS 16.9\% and IV 24.5\%). Larger differences on weekdays can be seen in the answer "more than 3 hours", where the BS group recorded 7\% and IV group 17\%. This could be explained precisely by the fact that the BS group of respondents has a significant part of their time on weekdays organized precisely because of school attendance. This time, "more than 3 hours", is comparable between the BS group and IVgroup in the weekend responses. Nevertheless, on the weekend between the BS group and IV group we can notice a difference in the time spent with friends in the times "1 - $2 \mathrm{~h}$ " and " 2 - $3 \mathrm{~h}$ ", which in total is $57.7 \%$ in BS group and $64.2 \%$ in IV group.

Table 3. Time spent with friends.

\begin{tabular}{|c|c|c|c|c|c|}
\hline \multicolumn{6}{|c|}{ Time spent with friends } \\
\hline \multirow{3}{*}{ Education form } & \multirow{3}{*}{ Time } & \multirow{2}{*}{\multicolumn{2}{|c|}{$\begin{array}{l}\text { Weekdays } \\
\text { Frequency }\end{array}$}} & \multirow{2}{*}{\multicolumn{2}{|c|}{$\begin{array}{l}\text { Weekends } \\
\text { Frequency }\end{array}$}} \\
\hline & & & & & \\
\hline & & Absolute & Relative & Absolute & Relative \\
\hline \multirow{7}{*}{ Basic school } & 0 & 4 & $5.6 \%$ & 12 & $16.9 \%$ \\
\hline & $1-30 \mathrm{~min}$ & 9 & $12.7 \%$ & 1 & $1.4 \%$ \\
\hline & $31-60 \min$ & 12 & $16.9 \%$ & 2 & $2.8 \%$ \\
\hline & $1-2 \mathrm{~h}$ & 27 & $38.0 \%$ & 16 & $22.5 \%$ \\
\hline & $2-3 h$ & 14 & $19.7 \%$ & 25 & $35.2 \%$ \\
\hline & More than $3 \mathrm{~h}$ & 5 & $7.0 \%$ & 15 & $21.1 \%$ \\
\hline & Total & 71 & $100.0 \%$ & 71 & $100.0 \%$ \\
\hline \multirow{7}{*}{ IV } & 0 & 4 & $7.5 \%$ & 7 & $13.2 \%$ \\
\hline & $1-30 \min$ & 3 & $5.7 \%$ & 0 & $0.0 \%$ \\
\hline & $31-60 \min$ & 13 & $24.5 \%$ & 1 & $1.9 \%$ \\
\hline & $1-2 \mathrm{~h}$ & 15 & $28.3 \%$ & 20 & $37.7 \%$ \\
\hline & $2-3 h$ & 9 & $17.0 \%$ & 14 & $26.4 \%$ \\
\hline & More than $3 \mathrm{~h}$ & 9 & $17.0 \%$ & 11 & $20.8 \%$ \\
\hline & Total & 53 & $100.0 \%$ & 53 & $100.0 \%$ \\
\hline
\end{tabular}

Another analyzed metric of our questionnaire survey was the findings concerning the visit to the preschool facility of the respondents - children. We found that $17 \%$ of IV respondents stated that the child did not attend preschool. A comparison of BS group and IV group showed that children attended preschool facilities for 3-4 years in total in more than two thirds $(67.6 \%)$ of BS respondents and in less than half $(45.3 \%)$ of IV respondents.

We also analyzed the occasions on which the child comes into contact or communication with other children. We categorized the text answers and then classified them into several areas listed in the following Table 4. As expected, there is a significant difference in the answer "school", where the BS group shows 30\% and IV group 8\%. The answer of "hobby activity" recorded the largest share, with 76\% in BS group and 76\% in IV group. Statistically significant differences can be observed in the "neighborhood" response (BS 10\% and IV 15\%), the "outdoor" response (BS $47 \%$ and IV 28\%) and the "meeting with other families / visits" response (BS 38\% and IV 47\%). Parents consider meeting with the extended family (BS 16.9\% and IV 18.9\%), various camps (BS 14.1\% and IV 11.3\%) to be an important area for their child's contact with other children. 
Table 4. On what occasions (regular or isolated) does your child have contact / communication with other children?

\begin{tabular}{ccccc}
\hline \multirow{2}{*}{ Response Categories } & \multicolumn{2}{c}{ Basic School } & \multicolumn{2}{c}{ IV } \\
\cline { 2 - 5 } & \multicolumn{2}{c}{ Frequency $(\mathbf{n}=\mathbf{7 1})$} & \multicolumn{2}{c}{ Frequency (n = 53) } \\
\cline { 2 - 5 } & Absolute & Relative & Absolute & Relative \\
\hline hobbies & 54 & $76.1 \%$ & 40 & $75.5 \%$ \\
family & 12 & $16.9 \%$ & 10 & $18.9 \%$ \\
neighborhood & 7 & $9.9 \%$ & 8 & $15.1 \%$ \\
outdoors & 33 & $46.5 \%$ & 15 & $28.3 \%$ \\
meetings with other families / visits & 27 & $38.0 \%$ & 25 & $47.2 \%$ \\
school & 21 & $29.6 \%$ & 4 & $7.5 \%$ \\
friends & 3 & $4.2 \%$ & 3 & $5.7 \%$ \\
camp & 10 & $14.1 \%$ & 6 & $11.3 \%$ \\
events for children & 6 & $8.5 \%$ & 4 & $7.5 \%$ \\
trips / vacation & 7 & $9.9 \%$ & 6 & $11.3 \%$ \\
sport & 0 & $0.0 \%$ & 1 & $1.9 \%$ \\
other & 9 & $12.7 \%$ & 7 & $13.2 \%$ \\
Total & $\mathbf{1 8 9}$ & $\mathbf{2 6 6 . 2 \%}$ & $\mathbf{1 2 9}$ & $\mathbf{2 4 3 . 4 \%}$ \\
\hline
\end{tabular}

We were also interested in the involvement of parents or the feeling of parents about their involvement and their own initiative to support their child in contact with other children. It was an item with the possibility of an open answer, where we again created categories from the answers obtained. The most common responses included information that contact with other children is provided by the child himself (BS $25 \%$ and IV 28\%), with $8 \%$ of IV respondents stating that they do not support / initiate these contacts in any way. In addition to support the organized activities, the parents themselves initiate or organize various meetings / games (BS 11\% and IV 9\%). According to the answers, the organization of visits (BS 13\% and IV 13\%) and family or community meetings (BS 17\% and IV 13\%) can be described as a significant role of parents. Equally important for us was finding out what preferences children have in leisure activities. To the question: "If you can make your own decisions, what do you like to do?" respondents could answer completely freely. We categorized their answers into the following areas:

- I don't know;

- I am with friends / siblings;

- Outdoors;

- I play;

- I do sport;

- I am with parents;

- I read;
- Electronics / TV;

- Drawing / Painting

- Fairy Tales;

- I Dance / Sing;

- Animal Care;

- Other.

The most frequent activities are included in Table 5.

Table 5. When you can make your own decisions, what do you like to do?

\begin{tabular}{ccccc}
\hline \multirow{2}{*}{ Response Categories } & \multicolumn{2}{c}{ Basic school } & \multicolumn{2}{c}{ IV } \\
\cline { 2 - 5 } & \multicolumn{2}{c}{ Frequency $(\mathbf{n}=\mathbf{7 1})$} & \multicolumn{2}{c}{ Frequency $(\mathbf{n}=\mathbf{5 3})$} \\
\cline { 2 - 5 } & Absolute & Relative & Absolute & Relative \\
\hline electronics / TV & 19 & $26.8 \%$ & 14 & $26.4 \%$ \\
friends / siblings & 15 & $21.1 \%$ & 9 & $17.0 \%$ \\
outdoors & 15 & $21.1 \%$ & 6 & $11.3 \%$ \\
I play & 12 & $16.9 \%$ & 18 & $34.0 \%$ \\
sport & 8 & $11.3 \%$ & 6 & $11.3 \%$ \\
reading & 7 & $9.9 \%$ & 5 & $9.4 \%$ \\
I draw / paint / make & 2 & $2.8 \%$ & 5 & $9.4 \%$ \\
\hline
\end{tabular}

Different factors can influence how children spend their leisure time, but they can also be influenced by specific people. So we found out if children perceive that someone influences them in spending their leisure time. The data obtained showed that children are most influenced by parents, followed by friends and coaches. A more significant 
difference between BS group and IV group is evident mainly in the answers indicating the father, who was marked in the BS group by $27 \%$ compared to $49 \%$ in IV group. We asked parents to express how much time their children spend on organized leisure activities on weekdays and on weekends. The data obtained from respondents - parents showed that many children spend several hours a week on organized leisure activities. On average, $52 \%$ of children in BS group and $60 \%$ of children in IV group spend at least an hour every day on organized leisure activities. From the obtained data it was readable that during the weekend the children spend much less time on organized activities. A large part of the respondents did not answer the question (BS 25\% and IV 31\%) and more than half (BS 63\% and IV 52\%) chose the option that the child spends 0 time. Nevertheless, respondents' units noted that children still have these activities at the weekend (BS 12\% and IV 17\%).

Table 6. What organized leisure activities does the child attend?

\begin{tabular}{ccccc}
\hline \multirow{2}{*}{ Activity } & \multicolumn{2}{c}{ Basic school } & \multicolumn{2}{c}{ IV } \\
\cline { 2 - 5 } & Frequency $(\mathbf{n}=\mathbf{7 1})$ & Frequency $(\mathbf{n}=\mathbf{5 3})$ \\
\cline { 2 - 5 } Absolute & Relative & Absolute & Relative \\
\hline none & 11 & $15.5 \%$ & 5 & $9.4 \%$ \\
sports & 39 & $54.9 \%$ & 34 & $64.2 \%$ \\
music & 22 & $31.0 \%$ & 14 & $26.4 \%$ \\
art & 17 & $23.9 \%$ & 15 & $28.3 \%$ \\
linguistic & 14 & $\mathbf{1 9 . 7 \%}$ & 18 & $\mathbf{3 4 . 0 \%}$ \\
scientific & 7 & $\mathbf{9 . 9 \%}$ & 11 & $\mathbf{2 0 . 8 \%}$ \\
literary and dramatic & 5 & $7.0 \%$ & 4 & $7.5 \%$ \\
Scout etc. associations & 15 & $21.1 \%$ & 15 & $28.3 \%$ \\
mathematical & 4 & $5.6 \%$ & 2 & $3.8 \%$ \\
craft & 1 & $1.4 \%$ & 3 & $5.7 \%$ \\
firefighters & 5 & $7.0 \%$ & 4 & $7.5 \%$ \\
cooking & 4 & $5,6 \%$ & 2 & $3.8 \%$ \\
Other ... & 6 & $8,5 \%$ & 6 & $11.3 \%$ \\
\hline Total answers & $\mathbf{1 3 9}$ & $\mathbf{1 9 5 . 8 \%}$ & $\mathbf{1 2 8}$ & $\mathbf{2 4 1 . 5 \%}$ \\
\hline
\end{tabular}

We also find out what organized leisure activities children do. According to parents, $15 \%$ of children from the BS group and $9 \%$ of children from IV group do not attend any activities. Respondents could select more than one answer when answering. Based on the obtained data, 1.9 selected activities per child in BS group and 2.4 selected activities per child in IV group. The most frequent activities include sports (BS 55\% and IV 64\%), music (BS 31\% and IV 26\%), art (BS 24\% and IV 28\%) and language activities (BS 20\% and IV 34\%). A general overview of leisure activities is given in Table 6.

In the category "Other ..." there were, for example, the following answers: it changes according to the needs and interests of children, Christian activities, breeding club, religion, trips, fishing. Equally important for us was finding out how much time the child spends on electronics. The variant "0 - 30 min" was marked for weekdays by $4 \%$ of BS respondents and $9 \%$ of IV, on weekends by $3 \%$ of BS group and $8 \%$ of IV group. The maximum hour spent at electronics per day was chosen by $23 \%$ of BS respondents and $17 \%$ of IV respondents at for weekdays, and on weekends $7 \%$ in BS group and $4 \%$ for IV group. The most frequent answer was the time "1 - 2 hours", which was chosen for weekdays by $38 \%$ of BS respondents and $28 \%$ of IV respondents, for the weekend it is $38 \%$ in BS group and $32 \%$ in IV group. On weekdays there is an interesting decrease in the number of respondents for the answer "2-3 hours" to 7\% in BS group and $11 \%$ in IV group, however on weekends it is $24 \%$ in BS group and $23 \%$ in IV group. $28 \%$ of children from the BS group and $34 \%$ of children from IV group spend more than 3 hours a day on electronics on weekdays and weekends.

Lifestyle also includes a variety of cultural and social experiences. So we found out how often a child visits a cinema, theater, museum / gallery, forest, playground or library. We did not notice any significant differences between the individual groups of primary schools and IV.

Using the analysis of the obtained data and their comparison, we can get answers to individual research questions:

\section{RQ1: What environment or activities do parents use to support their children's socialization?}

Respondents who participated in our questionnaire survey and are included in the BS group perceive that their children have the most opportunities to contact other children on the following occasions: hobby activities, outdoors, meetings with other families / visits and at school (frequency in order). In contrast, group of IV respondents mentioned the most opportunities for contact in this order of frequency: hobby activities, meetings with other families / visits, 
outdoors, in the neighborhood. Some parents do not consider it important to support / initiate their child's contacts with other children within the socialization (BS 25\% and IV 36\%). They do not engage in any way or leave the initiative to the child alone. However, the majority of parents (BS 58\% and IV 66\%) consider as their support the socialization and contact of their child with others, for example, arranging hobby activities, organizing meetings / games, various visits or arranging contact with family / community.

Attendance at pre-school education can often be perceived as an important thing for children to get used to the school system, to foreign authoritie,s to a new children's collective. However, as the parents' answers show, not everyone considers it an important part of development and education for their children. This resulted from data where $17 \%$ of IV respondents stated that the child did not attend pre-school education and 2-3 years of attendance was reported by $86 \%$ of BS respondents and $77 \%$ of IV respondents. We also found out from parents how often children visit different environments such as cinema, theater, museums / galleries, forest, playground or library. As expected, the most frequently visited playground was visited by $97 \%$ of children in the BS group and $92 \%$ of children in IV group every week. This was in the number of visitors followed by the forest environment, which is visited every week by $83 \%$ of children from IV group and 68\% from BS group. On average, 12\% of BS respondents and 10\% of IV respondents do not visit cultural facilities such as a library, cinema, theater or gallery at all.

\section{Q2: What is the motivation of parents to choose the homeschooling for their children?}

Among the most frequently mentioned reasons for applying for homeschooling we can include more space for the development of the child's talents, individual approach to the child and the choice of other forms and methods of education than the school applies. As a motivation for homeschooling we could complement the good experience of parents with this type of education, because based on the data obtained, a third of parents (32\%) have more than five years of experience with this type of education.

\section{RQ3: What are the differences in the socialization of pupils attending basic school against homeschoolers, resp. what are the differences in the involvement of children in the team, differences in leisure activities, differences in leisure preferences?}

The individual questionnaire items found out in what conditions children grow up, how they spend their time, what their preferences are in their activities or contact with other children. In summary, the data obtained did not reveal any significant differences in the way children grow up. In the individual answers, we can observe differences in the order of units of percentages of respondents in the BS group and IV group. 82\% of BS respondents and $87 \%$ of IV respondents expressed great satisfaction with relationships with other children or friends. A total of $91 \%$ of BS respondents and $99 \%$ of IV respondents reported that children like to spend time with friends / children outdoors, playing, exercising / doing sports or playing electronics (children reported more activities at the same time). Most children have a good friend or friends they get along with (BS 96\% and IV 93\%. In the same way, the time spent with these friends is comparable between the two analyzed groups. A greater difference in the conditions of socialization and inclusion in the peer group is evident between the BS group and IV group in the approach of parents to attending institutions providing pre-school education. Here, $17 \%$ of children from IV group did not attend kindergartens and similar facilities at all.

We noticed a difference between the BS group and IV group in the answers to the question of who the children turn to when they have any suffering. $15 \%$ of IV respondents and $4 \%$ of BS respondents indicated the option "for no one, I usually solve everything myself". This can be caused by upbringing, where children in homeschooling are often led more to independence in education and problem solving. In the approach to organized hobby activities, we found a difference in the data between the BS and IV respondents. When 15\% of children from BS group and 9\% from IV group do not attend these activities. Greater interest in "hobby groups" on IV side may be due to parents consciously looking for space to contact other children and at the same time complement their children's educational program. The values compared from the obtained data are comparable in the individual items, whether it is time spent outside, with electronics, time for organized activities or time spent with other children. However, a difference can be observed in the parents' approach to setting rules or restrictions for time spent with electronics. It could be said that IV parents are more benevolent in setting the rules, when $14 \%$ of the time spent with electronics does not limit them compared to $18 \%$ of BS parents. At the same time, the answer "Yes, we set the rules" was chosen by more parents in BS group than in IV group (BS $85 \%$ against IV $72 \%$ ).

When processing and evaluating the data, we did not notice any other significant differences between the compared groups. To measure how much time children spend on various activities, such as outdoors or electronics, we can use a comparison with the results of the Komárka [44]. In this representative research, the authors state that children spend an average of 1 hour and 48 minutes outdoors on weekdays. In the answers we received from the respondents to the questionnaire survey, we recorded the most frequent representation for the answer that children spend 2-3 hours outside on weekdays (BS $31 \%$ and IV 32\%), with almost a quarter of respondents stating that their children spend more than 3 hours outside on weekdays (BS 23\% and IV 25\%). Komárka [44] estimated the time spent by children on electronics at 
an average of 3.5 hours per day. This time includes time spent on TV, computer, tablet, mobile phone or playing PC games. From the questionnaire survey, we obtained data on the fact that $28 \%$ of BS respondents and $34 \%$ of IV respondents spend more than 3 hours on electronics. However, a significant part of the respondents stated a shorter time for using electronics. The time of 31 minutes to 2 hours was mentioned in total by $60 \%$ of BS respondents and $45 \%$ of IV respondents.

In the activities that children like / do best, we recorded answers in the questionnaire survey, which we can compare with the already mentioned by Komárka [44]. This is the most popular leisure time for children somewhere outside $(71 \%)$ and playing on electronics $(67 \%)$. Although we did not calculate such a high percentage in the data, children mentioned similar categories of activities in their answers. Specifically, more than a quarter of children (BS $27 \%$ and IV 26\%) reported electronics / TV in their response. Outdoor activities were not so represented, they were chosen by $21 \%$ of BS respondents and $11 \%$ of IV respondents. However, the large difference in representative research by Komárka [44] and in the questionnaire survey may be due to a different logic of questioning. In our questionnaire survey, children were free to list what they like to do when they can make their own decisions. It is possible that if they had predefined answers that would only "tick", the frequency in each of the selected activities would be completely different.

An important area analyzed was the reasons for applying for homeschooling. Parents who want to educate their child in the form of homeschooling must state their compelling reasons in the application they submit to the school principal. The three most cited reasons we noted in the questionnaire survey are "more space for talent development" (68\%), "individual approach" (66\%) and "choice of other forms and methods of education than the school offers" (66\%). The data obtained only partially correspond to the information found in the report [45], which indicates a share of responses of legal representatives of $73 \%$ for "choice of other forms of education", $6 \%$ for the preference of "individual approach" and $4 \%$ for "more space for talent development".

The interest in organized leisure activities was confirmed in the data obtained in the questionnaire survey. Only $9 \%$ of IV respondents stated that they did not address any of these activities. The figures cited in Tematická Report [45] then indicate $95 \%$ of the surveyed children enrolled in IV who participate in extracurricular leisure activities. The report also specifies, for example, activities in the sports section (55\%) or basic art education in art schools (51\%). We can compare this with our data, where sports activities were mentioned by $64 \%$ of respondents, and if we included "musical", "art", "literary and dramatic" activities in basic art education, then we would get $62 \%$ of respondents for these activities.

\section{5- Conclusion}

The aim of the presented article was to describe and compare how the socialization of children who fulfill compulsory school attendance in the form of homeschooling takes place. Socialization in both the home and school environment has its limits, but also its advantages. However, they are united by the same goal, and that is above all the healthy moral and social development of the individual. The "advantages" of socialization in the home environment can be considered that the home environment is safe, without negative influences that could adversely affect the child. Furthermore, it is time spent together that contributes to the development of family relationships. Last but not least, the fact that the child is approached individually at home, with respect for his or her current interests and needs, and so it is possible to develop his or her individuality. Conversely, "disadvantages" may be when the family is not involved in any support group or community and lives separately. It can also be limiting when there is only one child in the family who does not have the opportunity to cooperate with the siblings, interact, help each other and develop socially. The advantages associated with socialization at school are, for example, establishing new relationships, the possibility of comparison with classmates, competition and cooperation. The dark side of school socialization is the various socio-pathological phenomena that occurs at school, from bullying to alcohol and drugs. Furthermore, disrespect for individuality. The role of the teacher as a parent and the teacher as a stranger also has its strengths and pitfalls. As a teacher, a parent knows his child best and wants to provide the best for him. Possible difficulties may arise with insufficient professional knowledge of parents who do not have pedagogical education. Furthermore, it is the approach to the child in education or evaluation of educational results, which may not always be objective due to close relationships. On the other hand, if the teacher is a stranger, his approach is very objective, he can ensure discipline and compliance with the set rules. Above all, however, the teacher is an expert with a pedagogical education.

The research confirmed that parents significantly support their children in participating in organized leisure activities and are actively involved in mediating their child's contact with other children. It turned out that the motivation of parents for homeschooling of the child is based primarily on the interest in developing the talents of the child with an individual approach and the appropriate forms and methods of education. In the comparison of the examined groups, there were no significant differences in how the children perceive their friends, what their favorite activities are or how much time they spend with them. The difference was more noticeable in the parental approach in education, when setting some rules. The results of our study focused on the socialization of homeschoolers are in direct correlation with the findings concerning the socialization of homeshoolers published in prestigious international journals. In this context, we can specifically mention the correlation of the results with the studies [24, 48, 49, 50-52]. 
Unfortunately, it is not possible to make a sufficient comparison with the results of studies concerning the socialization of homeschoolers in the context of Central Europe with an emphasis on the Czech Republic. In some neighboring countries, such as Hungary or Germany, homeschooling is legally prohibited or not supported by schools and legislation, which states [54-58], in Slovakia considers its legislative anchoring in the coming school year and its basic principles are described with emphasis on Slovakia [59]. Thus, there is no basis for any comparison, whether of the basic aspects of homeschooling or with an emphasis on socialization. Even in the Czech Republic, homeschooling is still a novelty and a completely unexplored matter, only Kostelecká et al. (2018) [40], Kašparová [53] or Mertin [14] delt with the homeschoolers socialization and we identified, that results of our research correlated with the results of these studies. Štech [6] is one of the opponents of homeschooling and thus the promoter of an idea of insufficient socialization of homeschoolers, however, we are convinced that its conclusions have not been subjected to the longterm research, they are based only on assumptions and promotion of essentially outdated Czech education system. It was seen in last 18 months during the period of lockdown, closed schools, and the forced transition to distance learning, which in many ways resembled forms of homeschooling. In addition, we are convinced that the effects of homeschooling on the socialization of homeschoolers can be assessed only in the framework of longitudinal studies and we can expect relevant results in about 15 to 20 years. We hope that our study will become the starting point for some of the longitudinal studies.

\section{5-1-Limitations}

Our research was carried out at a time when life in Czech Republic was significantly affected by measures against the spread of Covid-19. Undoubtedly, this also affects the statements of respondents, which are already subject to restrictions on meetings of persons, restrictions on the operation of art schools and hobby groups, including sports.

\section{6- Declarations}

\section{6-1-Author Contributions}

V.Š.: conceptualization; A.O.: research preparation; K.B.: original draft preparation; V.Š., A.O., and K.B.: review and editing. All authors have read and agreed to the published version of the manuscript.

\section{6-2-Data Availability Statement}

Data sharing is not applicable to this article.

\section{6-3- Funding}

The presented article was prepared in the context of the solution of scientific research projects IGA VŠDTI No. 0002020 Secondary Socialization of Homeschoolers and UAE Gr. 10/29/21 P. SK Aspects of secondary socialization of homeschoolers in the conditions of the Czech Republic.

\section{6-4- Conflicts of Interest}

The authors declare that there is no conflict of interests regarding the publication of this manuscript. In addition, the ethical issues, including plagiarism, informed consent, misconduct, data fabrication and/or falsification, double publication and/or submission, and redundancies have been completely observed by the authors.

\section{7- References}

[1] Kunzman, Robert, and Milton Gaither. "Homeschooling: A comprehensive survey of the research." Other Education 2, no. 1 (2013): 4-59.

[2] Medlin, Richard G. "Homeschooling and the Question of Socialization Revisited.” Peabody Journal of Education 88, no. 3 (July 2013): 284-297. doi:10.1080/0161956x.2013.796825.

[3] Ray, Brian D. "A Systematic Review of the Empirical Research on Selected Aspects of Homeschooling as a School Choice." Journal of School Choice 11, no. 4 (October 2, 2017): 604-621. doi:10.1080/15582159.2017.1395638.

[4] Ray, Brian. “A Review of Research on Homeschooling and What Might Educators Learn?” Pro-Posições 28, no. 2 (August 2017): 85-103. doi:10.1590/1980-6248-2016-0009.

[5] Murphy, Joseph. "The Social and Educational Outcomes of Homeschooling." Sociological Spectrum 34, no. 3 (April 17, 2014): 244-272. doi:10.1080/02732173.2014.895640.

[6] Štech, Stanislav. "Škola, nebo domácí vzdělávání? Teoretická komplikace jedné praktické otázky." Pedagogika 53, no. 4 (2003): 418-436.

[7] KOŤA, J., and R. HAVLÍK. "Sociologie výchovy a školy. 1. vyd." Praha: Portál (2002). 
[8] Vágnerová, Marie. Vývojová psychologie. Dětství a dospívání. Karolinum Press, (2012).

[9] Kraus, Blahoslav, and Věra Poláčková. Člověk-prostředí-výchova: k otázkám sociální pedagogiky. Paido, (2001).

[10] Maňák, Josef, Prokop, Jiří and Jan Solfronk. (1998). "Kapitoly ze sociální pedagogiky a psychologie: př́ispěvek ke vzdělávání učitelů”. Brno: Paido.

[11] Řezáč, Jaroslav. (1998). "Sociální psychologie”. Brno: Paido

[12] Kostelecká, Yvona. "Domácí Vzdělávání a Legislativa. Studie Postkomunistických Států Střední Evropy.” Orbis Scholae 8, no. 1 (February 2, 2018): 9-26. doi:10.14712/23363177.2015.2.

[13] Rabušicová, Milada. “K sociologii výchovy, vzdělání a školy.” Masarykova univerzita, (1991).

[14] Mertin, Václav. "Pedagogicko-psychologické aspekty individuálního vzdělávání." Pedagogika 53, no. 4 (2003): 405-417.

[15] Ray, Brian. "Academic achievement and demographic traits of homeschool students: A nationwide study." Academic Leadership: The Online Journal 8, no. 1 (2010): 7.

[16] Statista (2020). Average number of own children under 18 in families with children in the United States from 1960 to 2019. Available online: https://statista.com/statistics/718084/average-number-of-ownchildren-per-family/ (accessed on May 2021)

[17] Jančaříková, Kateřina. "Domácí vzdělávání-příležitost pro děti se specifickými vzdělávacími potřebami: případová studie žáka s dyslexií1." (2016).

[18] Urbánková, Dana. (2018). "Setkání rodin domškoláků”. Available online: https://skolaprome.eu/akce-pro-deti/podpurne-akomunitni-skupiny (accessed on May 2021).

[19] Kašparová, Irena, and Marie Láníková. “Centralizovat, Nebo Rozvolnit? Analýza Diskuse o Individuálním Vzdělávání Na Půdě Poslanecké Sněmovny ČR Optikou Teorie Modernity Petera Wagnera.” Studia Paedagogica 21, no. 3 (2016): 41-61. doi:10.5817/sp2016-3-3.

[20] Kašparová, Irena. "SPOLU: Průvodce domácím vzděláváním v České republice." (2019).

[21] School Law 561/2004 Col. Available online: https://www.msmt.cz/dokumenty-3/skolsky-zakon-ve-zneni-ucinnem-od-25-82020 (accessed on May 2021).

[22] Konečný, Štěpán, Stanislav Ježek, and Jan Mareš. "Správa Elektronických Dotazníků (SED)." (2010).

[23] Nakonečný, Milan. “Sociální psychologie“Praha: Academia. 2009.

[24] Neuman, Ari, and Oz Guterman. "What Are We Educating Towards? Socialization, Acculturization, and Individualization as Reflected in Home Education.” Educational Studies 43, no. 3 (December 30, 2016): $265-281$. doi:10.1080/03055698.2016.1273763.

[25] Hartl, Pavel, Helena Hartlová-Císařová, and Karel Nepraš. "Velký psychologický slovník”. Portál, (2010).

[26] VandenBos, Gary R. APA dictionary of psychology. American Psychological Association, (2007).

[27] Roeckelein, Jon E., ed. Elsevier's dictionary of psychological theories. Elsevier, (2006).

[28] Stuart-Hamilton, Ian. Dictionary of psychological testing, assessment and treatment. Jessica Kingsley Publishers, (2007).

[29] Medlin, Richard G. "Home Schooling and the Question of Socialization." Peabody Journal of Education 75, no. 1-2 (April 2000): 107-123. doi:10.1080/0161956x.2000.9681937.

[30] Romanowski, Michael H. "Revisiting the Common Myths about Homeschooling." The Clearing House: A Journal of Educational Strategies, Issues and Ideas 79, no. 3 (January 2006): 125-129. doi:10.3200/tchs.79.3.125-129.

[31] Čábalová, Dagmar. Pedagogika. Grada, (2011).

[32] Alan, Josef. Etapy života očima sociologie. Panorama, (1989).

[33] Giddens, Anthony. Sociologie. Praha: Argo. (1999).

[34] Wyatt, Gary. Family ties: Relationships, socialization, and home schooling. University Press of America, (2008).

[35] Drenovsky, Cynthia K., and Isaiah Cohen. "The impact of homeschooling on the adjustment of college students." International Social Science Review 87, no. 1/2 (2012): 19-34.

[36] Blok, Henk. "Performance in Home Schooling: An Argument against Compulsory Schooling in the Netherlands." International Review of Education/Internationale Zeitschrift Für Erziehungswissenschaft/Revue Internationale de L'éducation 50, no. 1 (January 2004): 39-52. doi:10.1023/b:revi.0000018193.11161.42. 
[37] Murphy, Joseph. "The Social and Educational Outcomes of Homeschooling.” Sociological Spectrum 34, no. 3 (April 17, 2014): 244-272. doi:10.1080/02732173.2014.895640.

[38] Kostelecká, Yvona. “Doma, Nebo Ve Škole?” Studia Paedagogica 19, no. 1 (2014): 65-82. doi:10.5817/sp2014-1-4.

[39] Vahid, Amy Schechter, and Frank Vahid. Homeschooling: A Path Rediscovered for Socialization, Education, and Family. Lulu.com, 2007.

[40] Kostelecká, Yvona, Kateřina Machovcová, Andrea Beláňová, and Romana Štambergová. "Sebepojetí Absolventů Domácího Vzdělávání a Jejich Spolužáků: Pilotní Studie.” Pedagogická Orientace 28, no. 2 (August 15, 2018): $306-327$. doi:10.5817/pedor2018-2-306.

[41] Vigilant, Lee Garth, Lauren Wold Trefethren, and Tyler C. Anderson. "“You Can't Rely on Somebody Else to Teach Them Something They Don't Believe" Impressions of Legitimation Crisis and Socialization Control in the Narratives of Christian Homeschooling Fathers." Humanity \& Society 37, no. 3 (August 2013): 201-224. doi:10.1177/0160597613495841.

[42] Pearlman-Avnion, Shiri, and Mor Grayevsky. "Homeschooling, Civics, and Socialization: The Case of Israel." Education and Urban Society 51, no. 7 (December 19, 2017): 970-988. doi:10.1177/0013124517747973.

[43] Lebeda, Samantha. "Homeschooling: Depriving children of social development." Journal of Contemporary Legal Issues 16 (2007): 99.

[44] Nadace proměny Karla Komárka. České děti venku: Reprezentativní výzkum, kde a jak tráví děti svůj čas. Available online: http://www.nadace-promeny.cz/cz/vyzkum.html (accessed on April 2021).

[45] Tematická Zpráva - individuální vzdělávání žáků na 1. stupni základních škol. Available online: https://www.csicr.cz/cz/Dokumenty/Tematicke-zpravy/Tematicka-zprava-\%E2\%80\%93-Individualni-vzdelavani-zaku-na (accessed on April 2021).

[46] Vrátilová, Zdeňka. "Socializace dětí plnících povinnou školní docházku formou individuálního vzdělávání." Master thesis. Hradec Králové. (2021).

[47] Danišová Nikola. “Sekundární socializace dětí z domácího vzdělávání”. Bachelor thesis. Brno. (2020).

[48] Green-Hennessy, Sharon. "Homeschooled Adolescents in the United States: Developmental Outcomes." Journal of Adolescence 37, no. 4 (June 2014): 441-449. doi:10.1016/j.adolescence.2014.03.007.

[49] Uecker, Jeremy E., and Jonathan P. Hill. "Religious Schools, Home Schools, and the Timing of First Marriage and First Birth." Review of Religious Research 56, no. 2 (January 30, 2014): 189-218. doi:10.1007/s13644-014-0150-9.

[50] de Laat, Gita Mateja, Katarina Dadic, and Rona Bušljeta Kardum. "Homeschooling: Between Croatian Aspirations and Slovenian Reality." Educational Process: International Journal 9, no. 1 (2020): 7-22.

[51] Bridges, Margaret, Shana R. Cohen, Lyn Scott, Bruce Fuller, Rebecca Anguiano, Ariana Mangual Figueroa, and Alejandra Livas-Dlott. "Home Activities of Mexican American Children: Structuring Early Socialization and Cognitive Engagement." Cultural Diversity and Ethnic Minority Psychology 21, no. 2 (2015): 181-190. doi:10.1037/a0037927.

[52] Tulviste, Tiia, and Eve Kikas. "Qualities to Be Developed in Estonian Children at Home and at School." Journal of Applied Developmental Psychology 31, no. 4 (July 2010): 315-321. doi:10.1016/j.appdev.2010.03.002.

[53] Kašparová, Irena. "Skloňování vybraných forem domácího vzdělávání v Česku (aneb kdo v Česku potřebuje domácí vzdělávání)." Domácí vzdělávání (2020): 15.

[54] Kostelecká, Yvonna. "Domácí vzdělávání a legislativa. Studie postkomunistických států střední Evropy." Orbis scholae 8, no. 1 (2014): 9-26.

[55] Ray, Brian D. Research Facts on Homeschooling. ERIC Clearinghouse, (2015).

[56] Mikusová, Melinda. "Homeschooling Parents'demotivation and Remotivation Processes: A Pilot Study in Hungary." WoPaLP, Vol. 14, (2020):151-170.

[57] Spiegler, Thomas. "Home Education Versus Compulsory Schooling in Germany: The Contribution of Robert K. Merton's Typology of Adaptation to an Understanding of the Movement and the Debate about Its Legitimacy." International Perspectives on Home Education (2015): 151-165. doi:10.1057/9781137446855_11.

[58] Martin, Aaron T. "Homeschooling in Germany and the United States." Arizona Journal of International and Comparative Law. 27 (2010): 225.

[59] Mazur, Piotr, Ivana Rochovská, and Bibiana Kl'ačková. "The Issue of Homeschooling in Poland, the Czech Republic and Slovakia from the Perspective of Parents of Homeschooled Children." The New Educational Review 58, no. 4 (2019): 54-71. 